\title{
КОРПУС ОФИЦЕРОВ РУССКОГО ГЕНЕРАЛЬНОГО ШТАБА В ПЕРВУЮ МИРОВУЮ ВОЙНУ 1914-1918 ГГ. В ОЦЕНКЕ ЕЕ УЧАСТНИКОВ
}

\author{
О. Г. Некрасов \\ (Российский государственный аграрный университет - \\ МСХА им. К. А. Тимирязева
}

Аннотация: В статье рассматривается служба офищеров русского Генерального штаба накануне и во время Первой мировой войны, сложные и противоречивые оценки «мозга армии» представителями строевой массы офицерства, сильные и слабые стороны корпуса ученых офищеров.

Подготовлено на основе доклада автора на Всероссийской научной конференции «Военная история России», которая прошла в Московском гуманитарном университете 25 апреля 2016 г.

Ключевые слова: история войн; история России; Первая мировая война; Генеральный штаб; оперативное искусство; Академия Генерального штаба; военная карьера

\section{OFFICERS' CORPS IN THE RUSSIAN GENERAL STAFF DURING WWI (1914 - 1918) AS ASSESSED BY WAR PARTICIPANTS}

\author{
O. G. Nekrasov \\ (Russian State Agrarian University - MTAA)
}

\begin{abstract}
The article looks at the service of officers of the Russian General Staffbefore and during the First World War, as well as the complex and contradictory assessments of the contribution «the brain of the army» made, including in combat, and the strengths and weaknesses of the 'educated officers'.

This article is based on the paper presented at "The military history of Russia" conference, which was held at Moscow University for the Humanities on April 25, 2016

Keywords: history of warfare; history of Russia; World War I; Imperial General Staff; art of strategy; Military Academy of the General Staff; military career

Первая мировая война стала затянувшимся на четыре года побоищем старой Европы. Она опрокинула все расчеты мирного времени. Прежний испытанный инструмент - массовые регулярные армии (первая линия и резерв) - частью погибли, частью растворились в последующих мобилизациях всех возрастов. Война на истощение привела к реализации
\end{abstract}


концепции «вооруженного народа» в самом крайнем тотальном ее понимании: потребовала милитаризации государственной и общественной жизни целых наций, втянутых в казавшуюся бесконечной борьбу. Вдохновителем этой сложнейшей работы взялись быть Генеральные штабы воюющих стран. «Мозг армии» выявил стремление вылезть из черепной коробки армии и переместиться в голову всего государственного организма» (Шапошников, 1927: 13).

В мирное время офицеры Генерального штаба занимались изучением вероятных театров военных действий, перспективной оценкой военного, экономического и демографического потенциалов предполагаемых противников, составляли планы мобилизации, стратегического развертывания и сосредоточения войск, определяли направления потребных коммуникаций, разрабатывали оперативные решения начального периода войны. В русской армии эти офицеры служили как в войсковых штабах, так и в центральных управлениях военного ведомства; в штабах занимались оперативной и разведывательной деятельностью, связью и передвижением войск; они заведовали снабжением, служили по военной администрации и, наконец, командовали строевыми частями.

Своеобразие командного состава русской армии к началу Первой мировой войны состояло в том, что офицеры Генерального штаба составляли в нем особый корпус со своим мундиром (черный бархат, серебряный приклад и серебряный же аксельбант), своим порядком комплектования и прохождения службы.

Русский офицер Генерального штаба менял свой мундир на мундир строевой части только с получением полка. Став начальником дивизии в чине генерал-лейтенанта, он пользовался правом на пожизненное ношение мундира Генерального штаба (Генерал Тараканов, 1933: 21). Только в русской армии генералы Генерального штаба - «серебряные генералы» - командовали дивизиями и корпусами. Во всех других армиях генералы Генерального штаба занимались своим прямым делом - службой в штабах.

Два преимущества обособляли генштабистов в особый корпус, резко отделяли его от массы армейского офицерства, отличали от других категорий ученых офицеров - инженеров и артиллеристов (где тоже были свои преимущества, но скромнее) и делали соперником гвардии. Это ускоренное чинопроизводство и особая линия на получение полка.

На начало Первой мировой войны офицеры Генерального штаба, составляя около $2 \%$ общего числа офицеров в армии, занимали треть должностей командиров пехотных полков (Зайцев, 1961: 17).

Эти преимущества превращали офицера Генерального штаба в особый тип карьериста, чуждого как армии, так и гвардии, где Академию считали «специальным поприщем для карьеристов и ловчил» (Игнатьев, 1959: 123). 
Но гвардия и армия недолюбливали Генеральный штаб каждая посвоему. Гвардия не любила его как старая привилегированная корпорация породы и традиции, не любила новую привилегированную корпорацию знания и заслуги в соперничестве за влияние в армии. В гвардии существовала еще одна традиция, прямо враждебная карьерному духу Генерального штаба: запрет на производство в другой чин «за отличие». Поэтому «гвардейские части не допускали в свои ряды тех из своих сослуживцев, которые, закончив одну из академий, награждались за «отличные успехи в науках» следующим чином и, таким образом, имели несчастье обогнать своих сверстников по полку» (Деникин, 1929: 72).

Помимо привилегий гвардию сплачивал дух внутренней однородности, равенства «людей из общества». Она дорожила своей близостью ко двору и монарху, сознанием себя оплотом государства с его «историческими основами». В Генеральном штабе дух внутренней спайки объединял его в иной, но не менее тесный круг, круг посвященных в сокровенное знание «тайны войны». Недаром Генеральный штаб называли «черным духовенством» и не только из-за цвета мундира. Это было «иное» сообщество, где «друиды с белыми аксельбантами» за «монастырской стеной» своей обособленности и неприкосновенности «творили стратегию, готовили государство к войне, ковали инструмент, именуемый армией» (Шапошников, 1927: 13).

Кстати, и при дворе к Генеральному штабу относились с подозрением, как к чему-то «нестроевому и даже вредному» (Поливанов, 1924: 161). Русский державный вождь армии в отличие от германского императора предпочитал приближать не Генеральный штаб, а гвардию.

Неприятие гвардейских офицеров, дороживших правом служить «из чести», вызывали не «блеск и быстрота карьеры», а карьеризм Генерального штаба как мотивация служебного рвения, неприличное стремление выбиться за счет других, корпорация всезнаек и выскочек.

В армии недолюбливали Генеральный штаб (и в этом гвардия была солидарна с ней) как может строевое офицерство не любить штабных, начальствующих посредников между войсками и командными инстанциями. Служба в штабе в качестве ближайших и непосредственных сотрудников старших войсковых начальников неизбежно ставила офицеров Генерального штаба в привилегированное положение в сравнении со строевым офицерством.

Во время войны плохо скрываемая неприязнь строевиков к офицерам Генерального штаба только усиливалась, поскольку в привычном карьеризме Генерального штаба им претил отчетливый штабной привкус «героев боевого случая». Военный цензор Выборгской крепости в августе 1915 г. сообщал о настроениях строевого офицерства: «В особенности 
сильно преобладает чувство враждебности и зависти к офицерам Генерального штаба. Их обвиняют в интригах, происках и получении незаслуженных наград, приводятся сравнения со ссылкой на военные приказы, в которых награждения офицеров Генерального штаба орденом св. Георгия мотивировано тем, что такие офицеры передавали приказания и распоряжались под ружейным огнем. “Почему же не дают Георгия всем офицерам, которые всегда работают под ружейным огнем” (Российский государственный военно-исторический архив - далее РГВИА. Ф. 2031. ОП. 1. Д. 1184. Л. 4).

Если для гвардии офицер Генерального штаба был неприятен как нетерпеливый выскочка за счет товарищей, то в армии болезненно замечалась, прежде всего, корпоративная солидарность Генерального штаба, когда за явными преимуществами виделась скрытая система взаимной протекции, сплачивающая всех его членов. А. А. Брусилов отмечал «постоянное, быстрое перемещение этих офицеров с одной должности на другую для более быстрого продвижения вперед»; «такое перелетание с место на место» было бы невозможно без вмешательства Ставки, «желавшей быстрее выдвигать своих академический товарищей, которые без приказа сверху не имели бы возможности столь резво прыгать» (Брусилов, 1948: 64).

Впрочем, амбиции молодого Генерального штаба простирались дальше штабных интриг и негласных влияний. Брусилов вспоминал, как за несколько лет до войны он был свидетелем спора двух молодых офицеров Генерального штаба с неким строевым подполковником. Те доказывали, что ученый корпус офицеров должен давать из своей среды преимущественно полководцев, вождей армии, а служба Генерального штаба есть только подготовительная ступень на пути к высокому поприщу (там же: 163).

Неприятие вызывало нетерпеливое желание молодых генштабистов уже на «подготовительной ступени» почувствовать себя водителями армий, творцами «больших оперативных решений», которые определяют ход и исход боя.

Но вся враждебность, ревность, зависть строя армии, гвардии и специальных родов войск сосредоточено выразилась в понятии «момент» в представлении об определенном типе штабного офицера. «Моментами» называли генштабистов за пристрастие многих из них к таким выражениям, как «надо поймать момент», «это момент для атаки» (Игнатьев, 1959: 122). «Моменты» - в основном молодежь Генерального штаба - держали себя самоуверенно, высокомерно и наставительно даже со старшими начальниками, а с «меньшей братией» обращались небрежно, бестактно и даже грубо (Геруа, 1969: 150-151).

Но, справедливости ради надо отметить, именно свою штабную ра- 
боту офицеры Генерального штаба умели делать хорошо. А. А. Игнатьев пишет, что генштабистов полагалось ругать только до той минуты, когда надо было писать приказ или отдавать распоряжение; в такое время лишиться офицера Генерального штаба было горше всего (Игнатьев, 1959: 252). Это же подтверждает Б. В. Геруа: «В войсковом быту ценность офицера Генерального штаба сказывались немедленно во время серьезного испытания и на войне. Жаловались, если их не хватало, и хватались за них именно те недоросли и невежды, которые в спокойные времена относились к ним особенно критически и насмешливо» (Геруа, 1969: 153).

Даже те строевые начальники, которые, как Брусилов, не недолюбливали генштабистов, признавали, что «за некоторыми исключениями, офицеры Генерального штаба в эту войну работали хорошо, умело и старательно выполняли свой долг» (Брусилов, 1948: 64).

Подлинно слабые стороны русского Генерального штаба, в сущности, остались за пределами критики, исходящей из строя армии, но для самих генштабистов они не были тайной. Вместе с сильными профессиональными качествами они закладывались еще в Академии. Б. М. Шапошников, будущий советский маршал, вспоминал, что из Академии выходили «больше теоретики, чем практики, от них самих уже зависело сделаться практиками» (Шапошников, 1974: 170).

С. В. Кирей, выдающийся артиллерист Первой мировой войны, в свое время закончивший Академию Генерального штаба, вспоминал: «...сколько тягостей и жертв принесла пехота благодаря нашему пренебрежению к тылу. Генштаб, который фактически всем распоряжался, давал войскам задачи, не считаясь с работой тыла, не помогая ему и не контролируя его отношения к войскам» (РГВИА. Ф. 260. Оп. 1. Д. 9. Л. 9 (об)).

С этим была связана еще одна слабость Генерального штаба: тот же С. В. Кирей отмечал «незнание нашим высшим командным составом и генштабом техники вообще и артиллерии в частности. Летчики, броневики, автомобилисты, тяжелые артиллеристы «втирали очки» как хотели, проконтролировать их не умели» (РГВИА. Ф.260. ОП. 1. Д. 9. Л. 34).

Подводя всему сказанному некоторый итог, можно отметить, что корпус офицеров Генерального штаба воспринимался остальной армией скорее как привилегированный род войск, нежели кадровая элита всей армии, научно подготовленная руководить ею. Несмотря на разнообразие функций русского Генерального штаба, на востребованность его офицеров в самых различных областях военной службы, он был для строевых офицеров, прежде всего, «штабом», далеким от войск и тягот окопной войны, и тем больше штабным «черным войском», чем сильнее хотел в лице своих наиболее амбициозных представителей быть «генеральным», то есть стремился быть вождем армии. 


\section{СПИСОК ЛИТЕРАТУРЫ}

Брусилов, А. А. (1948) Мои воспоминания. М. : Военное издательство народного комиссариата вооруженных сил Союза ССР. 263 с.

Геруа, Б. В. (1969) Воспоминания о моей жизни : в 2 т. Париж : Танаис. T. I. 275 c.

Деникин, А. И. (1929) Старая армия : в 2 т. Париж : Родник. Т. I. 114 с.

Зайцев, А. А. (1961) Служба Генерального штаба. Нью-Йорк : Военный Вестник. 209 с.

Игнатьев, А. А. (1959) Пятьдесят лет в строю : в 2 т. М. : Государственное издательство художественной литературы. Т. 1.590 с.

Поливанов, А. А. (1924) Из дневников и воспоминаний по должности военного министра и его помощника 1907-1916 гг. М. : Высший военный редакционный совет. 240 с.

Генерал Тараканов (1933) Служба Генерального штаба : лекции, читанные в 1932-1933 учебном году на старшем классе. Белград. 222 с.

Шапошников, Б. М. (1974) Воспоминания. Военно-научные труды. М. : Воениздат. 576 с.

Шапошников, Б. М. (1927) Мозг армии : в 3 т. М. : Военный вестник ; Государственное военное издательство. Т. І. 259 с.

Дата поступления: 15.06.2016 2.

Некрасов Олег Георгиевич - старший преподаватель кафедры истории Гуманитарно-педагогического факультета Российского государственного аграрного университета - МСХА им. К. А. Тимирязева. Адрес: 127550, Россия, г. Москва, ул. Лиственничная аллея, д. 4а. Тел.: +7 (499) 976-18-52. Эл. адрес: history@timacad.ru

Nekrasov Oleg Georgievich, Senior lecturer, Department of History, Faculty of Humanities and Education, Russian State Agrarian University MTAA. Postal address: 4a Listvennichnaya alleya St., 127550 Moscow, Russian Federation. Tel.: +7 (499) 976-18-52. E-mail: history@timacad.ru 